Review

\title{
A Review on the Recycling of the Concrete Waste Generate from the Decommissioning of Nuclear Power Plants
}

\author{
Ji-Hun Jeon, Woo-Chun Lee, Sang-Woo Lee, Soon-Oh Kim* \\ Department of Geology and Research Institute of Natural Science (RINS), Gyeongsang National University (GNU)
}

*Corresponding author : sokim@gnu.ac.kr

\section{ARTICLE INFORMATION}

Manuscript received 21 April 2021

Received in revised form 22 April 2021

Manuscript accepted 22 April 2021

Available online 28 April 2021

DOI : http://dx.doi.org/10.9719/EEG.2021.54.2.285

\section{Research Highlights}

- The waste concrete powder from the nuclear-decommissioning facilities has been utilized as recycling cement.

- Most of soil waste has not been used or recylced, and the efforts are needed to produce non-sintered cement using the clay minerals in the soil waste.

- The recycling of concrete and soil wastes can render collateral benefits such as the volume reduction and safe disposal of radioactive wastes.

\begin{abstract}
Globally, nuclear-decommissioning facilities have been increased in number, and thereby hundreds of thousands of wastes, such as concrete, soil, and metal, have been generated. For this reason, there have been numerous efforts and researches on the development of technology for volume reduction and recycling of solid radioactive wastes, and this study reviewed and examined thoroughly such previous studies. The waste concrete powder is rehydrated by other processes such as grinding and sintering, and the processes rendered aluminate $\left(\mathrm{C}_{3} \mathrm{~A}\right), \mathrm{C}_{4} \mathrm{AF}, \mathrm{C}_{3} \mathrm{~S}$, and $\beta-\mathrm{C}_{2} \mathrm{~S}$, which are the significant compounds controlling the hydration reaction of concrete and the compressive strength of the solidified matrix. The review of the previous studies confirmed that waste concretes could be used as recycling cement, but there remain problems with the decreasing strength of solidified matrix due to mingling with aggregates. There have been further efforts to improve the performance of recycling concrete via mixing with reactive agents using industrial byproducts, such as blast furnace slag and fly ash. As a result, the compressive strength of the solidified matrix was proved to be enhanced. On the contrary, there have been few kinds of researches on manufacturing recycled concretes using soil wastes. Illite and zeolite in soil waste show the high adsorption capacity on radioactive nuclides, and they can be recycled as solidification agents. If the soil wastes are recycled as much as possible, the volume of wastes generated from the decommissioning of nuclear power plants (NPPs) is not only significantly reduced, but collateral benefits also are received because radioactive wastes are safely disposed of by solidification agents made from such soil wastes. Thus, it is required to study the production of non-sintered cement using clay minerals in soil wastes. This paper reviewed related domestic and foreign researches to consider the sustainable recycling of concrete waste from NPPs as recycling cement and utilizing clay minerals in soil waste to produce unsintered cement.
\end{abstract}

Keywords : nuclear-decommissioning facilities, radioactive waste, recycling cement, non-sintered cement, solidifier

Citation: Jeon, J.-H., Lee, W.-C., Lee, S.-W., Kim, S.-O. (2021) A Review on the Recycling of the Concrete Waste Generate from the Decommissioning of Nuclear Power Plants. Korea Economic and Environmental Geology, v.54, p.285-297, doi:10.9719/ EEG2021.54.2.285. 


\title{
해설
}

\section{원전 해체 콘크리트 폐기물의 재활용에 대한 고찰}

\author{
전지훈 · 이우춘 · 이상우 · 김순오*
}

경상국립대학교 지질과학과 및 기초과학연구소(RINS)

*책임저자 : sokim@gnu.ac.kr

\section{요 약}

전세계적으로 해체 대상 원자력 시설이 증가하고 있으며, 이러한 원자력 시설을 해체하게 되면 수십만 톤의 콘크리트, 토양, 금 속 등의 폐기물이 발생한다. 따라서 고상 방사성 폐기물 감용 및 재활용 기술에 대한 기존 연구를 면밀히 검토할 필요가 있다. 폐콘크리트 미분말은 소성 및 분쇄와 같은 추가적인 공정을 통하여 재수화 반응이 일어나며, 시멘트 수화 반응 및 고화체 압축 강도에 영향을 미치는 주요 화합물인 aluminate $\left(\mathrm{C}_{3} \mathrm{~A}\right), \mathrm{C}_{4} \mathrm{AF}, \mathrm{C}_{3} \mathrm{~S}, \beta-\mathrm{C}_{2} \mathrm{~S}$ 가 생성된다. 기존 연구를 통하여 폐콘크리트 미분말을 재생 시멘트로 재활용할 수 있음을 확인하였으나, 골재의 혼입으로 인한 고화체의 강도 저하와 같은 문제점에 대한 해결방안은 현재까지 연구되지 않았다. 이러한 문제점을 보완하기 위하여 산업부산물인 고로슬래그, 비산회를 성분 조정재로 혼합하여 재 생 시멘트의 성능을 증진시키는 연구가 수행되었으며, 고화체의 압축강도가 증진되는 것을 확인하였다. 그러나, 폐토양을 재활 용한 비소성 시멘트의 제조에 대한 연구는 많이 수행되지 않았다. 폐토양 내 함유된 일라이트와 제올라이트는 방사성 핵종에 대한 흡착능이 우수하며, 이를 고화재로 재활용하면 원전 해체 폐기물의 부피를 저감함과 동시에 방사성 폐기물을 안전하게 담 지할 수 있는 효과를 도출할 수 있다. 이러한 이유에서 폐토양 내 점토 광물을 이용한 비소성 시멘트의 제조에 대한 연구가 필 요하다. 본 연구에서는 기존에 수행된 국내외 연구를 통하여 원전 해체 폐기물인 콘크리트의 재생 시멘트로서 재활용 가능성 및 개선 방안과 더불어 폐토양 내 점토 광물을 이용한 비소성 시멘트 제조에 대한 연구 필요성에 대하여 고찰하였다.

주요어 : 원전 해체 시설, 방사성 폐기물, 재생 시멘트, 비소성 시멘트, 고화재

\section{1. 서 론}

노후화된 원자력 시설의 해체는 지속적 원자력 산업을 위한 순환과정의 일환으로서, 국내외적으로 해체 대상이 되는 원자력 시설이 증가할 것으로 예상되고 있다(Moon, 2013; Song, 2016). 기존 원전의 수명 연장과 신규 원전 의 추가 및 해체 시설 등의 각종 원자력 시설에서 발생 하는 방사성 폐기물은 꾸준히 증가하는 추세이다. 국제 원자력기구(international atomic energy agency, IAEA)의 통계에 의하면, 전 세계의 원전은 2020년 02월 기준으로 445 기가 가동 중이며, 192 기가 영구 정지되어 있으며, 이 중 21기만 해체가 완료된 상태에 있다(Lee, 2020; IAEA, 2021). 국내 원자력 시설은 고리 1호기와 월성 1호기가 영구 정지된 상태이며, 2029년까지 순차적으로 12 기가 영구 운전 정지되어 원전 해체될 예정이다. 이러한 원자 력 시설을 해체하게 되면 수십만 톤의 폐기물이 발생하 기 때문에 폐기물에 대한 감용 및 재활용 기술의 확보는 매우 중요한 문제로 대두되고 있다(Lee et al., 2016; Choi et al., 2020; Lee, 2020). 그러나, 우리나라는 아직 이러 한 건설 폐기물 재활용에 대한 관심은 여전히 미흡하며, 재활용 기술 수준 또한 아직까지 미비한 편이다(Ahn et al and Park, 2013; Lee et al., 2018).

원자력 시설 건물은 철근콘크리트 구조로 되어 있어 원 전 해체 시에는 다량의 콘크리트 방사성 폐기물과 폐 토 양, 금속폐기물 등이 발생할 것으로 예상된다(Min et al., 2009; Abdel Geleel and Mahmoud, 2012). 원전 해체로 인하여 발생되는 콘크리트 폐기물은 대부분 극저준위로 분류되지만, 전체 폐기물 중 콘크리트 폐기물이 60-80\% 로 상당한 부분을 차지한다(Sawada et al., 2005; Min et al., 2009; Sasaki et al., 2009). 이러한 콘크리트 폐기물 을 재활용하기 위해 열처리 및 기계적 처리 방법을 통하 여 골재와 페이스트를 분리하며, 골재의 경우 분류된 골 재를 크기에 따라 $5 \mathrm{~mm}$ 체가름 기준으로 굵은 것을 순환 굵은 골재, 작은 것을 순환 잔골재로 재활용하는 것이 일 반적이다(Cheon et al., 2018). 순환 골재 생산과정에서 발생되는 시멘트 페이스트와 잔골재 미분과 같은 폐미분 말은 소성 및 분쇄와 같은 추가 공정을 통하여 재수화 반응이 일어날 수 있으며, 폐기물 처리용 소재 제조 시 필요한 무기물질인 calcium silicate hydrate $(\mathrm{CSH})$, $\mathrm{Ca}(\mathrm{OH})_{2}, \mathrm{SiO}_{2}$ 등이 다량 함유되어 있어서 이를 원전 해 체 과정에서 발생하는 방사성 폐기물 처리용 고화재로 재활용할 경우 방사성 폐기물 발생량 및 처분 비용을 저 
감할 수 있다(Malviya, 2006; Kim et al., 2020). 또한, 폐 토양 내 실트 및 점토에는 방사성 핵종의 흡착성능이 우 수한 illite, zeolite와 같은 점토 광물이 존재하며, 이를 고 화재로 재활용하여 핵종의 흡착율을 증가시켜 방사성 폐 기물의 안전한 처분이 가능할 것으로 예상된다. 본 연구 에서 사용된 고화재와 고화체의 용어간 차이점이 모호할 수 있기 때문에 두 용어의 차이를 간략하게 설명하면, 고 화(solidification)는 굳치는 현상을 표현하는 개념이며, 여 기에 사용되는 재료를 고화재, 고화재를 이용하여 방사 성 폐기물 등을 담지하여 제조한 물체를 고화제라 한다 (Lee et al., 2015).

폐콘크리트 내 시멘트 페이스트와 잔골재 미분말과 같 은 폐미분말을 재생 시멘트로 재활용한 연구는 2000년대 이후 지속적으로 수행되어왔으나, 내부 잔골재 성분으로 인한 강도 부족 및 화학 성분의 불균형 등의 문제점이 남아있다(Shin, 2003; Kang et al., 2011). 이러한 문제점 을 보완하기 위하여 폐콘크리트 미분말과 산업부산물인 고로슬래그, 비산회(fly ash)를 성분조정재로 혼합하여 재 생 시멘트의 성능을 증진시키는 연구가 수행되고 있다 $(\mathrm{Oh}$ and Kim, 2002; Jang, 2003; Oh, 2005; Yeon et al., 2008).

그러나, 방사화가 진행된 폐콘크리트를 재생 시멘트 및 재생 골재로 재활용한 연구는 미흡한 실정이다. 현재까 지 수행된 대표적인 연구는 프랑스의 Commissariat à L'énergie Atomique et Aux 'Energies Alternatives (CEA), 네덜란드의 Keuring van Electrotechnische Materialen (KEMA), 영국의 British Nuclear Fuel Limited (BNFL)과 공동으로 연구한 $\mathrm{DECO}$ 공정으로서, $600^{\circ} \mathrm{C}$ 이상의 고온 열처리를 통한 방사성 콘크리트 폐기물 일부를 재활용할 수 있음을 제시하였다(Binkhorst and Cornelissen, 1998; Min et al., 2009; Mun et al., 2017).

본 논문은 기존 문헌 연구를 통해 원자력 시설 해체 시 다량으로 발생하는 폐콘크리트, 폐토양을 재생 시멘트 및 비소성 시멘트로 재활용하기 위해 건설 폐기물과 같은 일반적으로 발생하는 콘크리트 폐기물을 재활용한 기존 의 관련 문헌들에 대하여 설명하고자 한다. 세부적으로 는 (1) 콘크리트 폐기물을 이용한 재생 시멘트의 재활용 가능성, (2) 콘크리트 폐기물과 산업부산물을 이용한 재 생 시멘트의 고품질화, (3) 점토 광물 및 산업부산물을 이용한 비소성 시멘트의 활용 가능성에 대하여 알아보았 으며, (4) 기존 문헌 연구 결과로부터 도출된 시사점과 향후 연구가 필요한 부분에 대하여 제안하고자 한다.

\section{2. 폐콘크리트를 이용한 재생 시멘트 활용 가능성}

원자력 시설 해체 시 발생되는 콘크리트 폐기물을 재
생 시멘트로 재활용하기 위해서는 1차적으로 열처리 및 기계적 처리 방법을 통한 골재와 페이스트를 분리하고 2 차적으로 소성 및 분쇄와 같은 공정을 통하여 재생 시멘 트로 활용할 수 있다(Byun et al., 2004). 이러한 폐콘크 리트를 재생 시멘트로 재활용하기 위하여 폐콘크리트 및 재생 시멘트에 대한 화학적 및 광물학적 특성을 분석한 연구들이 현재까지 수행되고 있다(Park et al., 2004; Kim et al., 2005; Lee et al., 2013; Kim and Chung, 2019). 폐 콘크리트의 화학적 조성은 모든 연구에서 유사하게 나타 났으며, 폐콘크리트를 소성 처리함에 따라, 시멘트 수화반 응 및 고화체의 압축강도에 영향을 미치는 주요 화합물인 aluminate $\left(\mathrm{C}_{3} \mathrm{~A}, 3 \mathrm{CaO} \cdot \mathrm{SiO}_{2}\right), \mathrm{C}_{4} \mathrm{AF}\left(\right.$ Ferrite, $\left.4 \mathrm{CaO} \cdot \mathrm{Al}_{2} \mathrm{O}_{3} \cdot \mathrm{Fe}_{2} \mathrm{O}_{3}\right)$, $\mathrm{C}_{3} \mathrm{~S}$ (Alite, $3 \mathrm{CaO} \cdot \mathrm{SiO}_{2}$ ), $\beta$ - $\mathrm{C}_{2} \mathrm{~S}\left(\right.$ Belite, $2 \mathrm{CaO} \cdot \mathrm{SiO}_{2}$ )가 생성 되는 것을 확인하였다(Park et al., 2004; Shi and FernándezJiménz, 2006; Saleh et al., 2019). 이러한 주요 화합물은 식 (1)-(2)와 같은 수화반응을 일으켜 시멘트의 강도를 발 현시킬 수 있다(Kim and Jo, 1999).

$2\left(2 \mathrm{CaO} \cdot \mathrm{SiO}_{2}\right)+4 \mathrm{H}_{2} \mathrm{O} \longrightarrow 3 \mathrm{CaO} \cdot 2 \mathrm{SiO}_{2} \cdot 3 \mathrm{H}_{2} \mathrm{O}+\mathrm{Ca}(\mathrm{OH})_{2}$ (1)

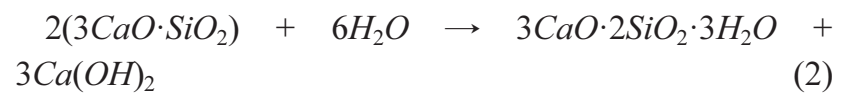

폐콘크리트를 재생 시멘트로 재활용한 기존의 연구에 서 골재의 혼입으로 인한 고화체의 압축강도 저하와 같 은 문제점이 항상 제기되어 왔으나, 골재와 페이스트의 분리 기술이 확립되지 않음에 따라, 산업부산물을 첨가 제로 이용한 재생 시멘트의 성능을 증진시킬 수 있는 방 안을 제외한 연구는 미흡한 실정이다.

2절에서는 기존에 수행된 문헌들을 통하여 폐콘크리트 에서 파생되는 폐 미분말, 골재를 재생 시멘트로 재활용 하기 위하여 (1) 폐콘크리트의 주요 화학적 및 광물학적 특성과 같은 기초 특성에 대하여 알아보았으며, (2) 폐콘 크리트를 재생 시멘트로 이용하여 제조한 고화체의 모르 타르 유동성, 압축강도, 침출성 등에 대하여 알아보았다.

\section{1. 폐콘크리트를 이용한 재생 시멘트의 특성}

본 연구의 목적은 원전 해체 시 발생되는 폐콘크리트 를 재생 시멘트로 재활용한 기존의 문헌에 대하여 고찰 하는 것이지만, 실제 방사화가 진행된 폐콘크리트는 일 반 실험실로 반출이 불가능하다. 이에 따라서, 본 연구에 서 설명하는 폐콘크리트는 실제 원전에서 채취한 미분이 아닌 일반 폐콘크리트로부터 선별한 것으로서, 이를 재 활용한 재생 시멘트로서의 활용 가능성을 평가하는 데 의의가 있다. 
Table 1. The chemical properties of portland cement and waste concrete powder

\begin{tabular}{|c|c|c|c|c|c|c|c|c|c|c|c|}
\hline & \multirow{2}{*}{ Type } & \multirow{2}{*}{$\begin{array}{l}\text { Particle size } \\
(\mathrm{mm})\end{array}$} & \multicolumn{8}{|c|}{ Chemical composition (wt\%) } & \multirow{2}{*}{ References } \\
\hline & & & $\mathrm{CaO}$ & $\mathrm{SiO}_{2}$ & $\mathrm{Al}_{2} \mathrm{O}_{3}$ & $\mathrm{Fe}_{2} \mathrm{O}_{3}$ & $\mathrm{MgO}$ & $\mathrm{SO}_{3}$ & Others & LOI & \\
\hline \multirow{2}{*}{ Portland cement } & \multirow{2}{*}{-} & \multirow{2}{*}{-} & 63.3 & 24.7 & 5.8 & 2.5 & 2.0 & 1.5 & 0.1 & - & Yeon et al., 2008 \\
\hline & & & 61.6 & 21.4 & 4.7 & 3.5 & 2.3 & 2.1 & - & 2.9 & Mun et al., 2017 \\
\hline \multirow{13}{*}{$\begin{array}{c}\text { Waste cement } \\
\text { powder }\end{array}$} & \multirow{3}{*}{ Paste material } & $<0.15$ & 62.0 & 21.3 & 5.4 & 3.5 & 3.3 & 1.64 & - & 1.0 & Oh, 2005 \\
\hline & & $<0.15$ & 56.7 & 17.2 & 4.5 & 2.5 & 2.4 & 1.0 & - & - & Ahn and Park, 2013 \\
\hline & & - & 56.5 & 17.9 & 3.8 & 3.1 & 1.9 & 1.6 & - & 14.1 & Mun et al., 2017 \\
\hline & \multirow{10}{*}{$\begin{array}{l}\text { Recycled } \\
\text { aggregate }\end{array}$} & $<1$ & 12.2 & 68.5 & 10 & 4 & 0.8 & - & & - & Min et al., 2009 \\
\hline & & $<0.15$ & 22.8 & 39.4 & 10.1 & 2.3 & 1.8 & - & & - & Ahn and Park, 2013 \\
\hline & & $>20$ & 25.3 & 35.6 & 8.7 & 18.3 & - & - & 12.1 & - & \multirow{5}{*}{ Shin et al., 2013} \\
\hline & & $5-20$ & 36.8 & 28.9 & 6.7 & 15.9 & - & - & 11.6 & - & \\
\hline & & $2.5-5$ & 40.1 & 28.2 & 7.4 & 13.4 & - & - & 11.0 & - & \\
\hline & & $0.4-2.5$ & 44.2 & 26.1 & 7.0 & 12.5 & - & - & 10.2 & - & \\
\hline & & $<0.4$ & 50.4 & 21.6 & 5.9 & 13.0 & - & - & 9.0 & - & \\
\hline & & - & 24.1 & 48.8 & 12.8 & 4.8 & 2.3 & 1.2 & 6.35 & - & Kim et al., 2015 \\
\hline & & - & 26.2 & 49.1 & 8.3 & 2.0 & 1.6 & 1.0 & & 9.7 & Mun et al., 2017 \\
\hline & & - & 14.3 & 57.1 & 10.8 & 5.4 & 1.9 & 1.0 & 9.51 & 4.2 & Jeong et al., 2017 \\
\hline
\end{tabular}

폐콘크리트를 이용한 재생 시멘트는 순환 골재 생산과 정에서 발생되는 시멘트계 폐콘크리트 미분말을 이용하 며, 입도 크기 및 잔골재의 혼입에 따라 미분말의 화학 적 성분은 상이할 수 있다. 이러한 폐콘크리트 미분말을 재생 시멘트로 이용한 기존 문헌 조사를 통한 폐콘크리 트 미분말의 화학적 성분을 Table 1에 정리하였다. 페이 스트 모재에서 파생된 폐콘크리트 미분말의 경우 포틀랜 드 시멘트와 화학 성분이 유사하게 나타났다. 일반적인 순환 골재로부터 파생된 폐콘크리트 미분말의 경우 잔골 재가 혼입됨에 따라 $\mathrm{SiO}_{2}$ 함량이 증가하였으며, $\mathrm{CaO}$ 함 량은 약 $30 \%$ 미만의 함량으로 감소하는 것으로 나타났 다. 폐콘크리트 미분말의 입자 크기가 감소할수록 시멘 트의 수화반응에 영향을 미치는 $\mathrm{CaO}$ 함량이 증가하였으 며, 이를 통하여 재생 시멘트의 제조에 있어 세립질의 폐 콘크리트 미분말보다 미립질의 폐콘크리트 미분말이 더 욱 적합한 것을 확인하였다. Ahn et al. (2013)은 잔골재 미분말의 혼입에 따른 폐콘크리트 미분말 내 잔골재 치 환에 따른 구성 성분의 함량 변화를 통하여 $\mathrm{CaO}$ 성분이 점차 감소하게 되는 것을 제시하였으며, 순환 골재에서 발생되는 폐콘크리트 미분말의 평균 잔골재 성분이 50$70 \%$ 함유되어 있음을 제시하였다(Fig. 1). 그러나, Shin et al. (2013)은 순환 골재 폐콘크리트 미분말의 입도가 감소함에 따라 $\mathrm{CaO}$ 함량이 증가하며, 최대 $50.4 \mathrm{wt} \%$ 로 나타남을 확인하였다. 이를 통하여, 순환 골재 원료인 폐 콘크리트의 구성 성분이 상이함에 따라 화학적 성분이 달라질 수 있으며, 잔골재의 혼입을 줄일 수 있는 기술

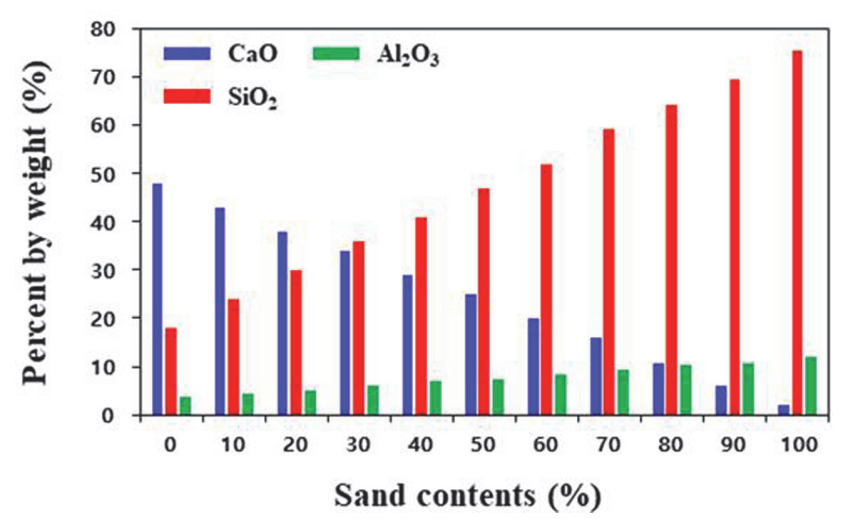

Fig. 1. Variation in the content of constituents according to the replacement of waste concrete powder and fine aggregate (data from Ahn et al., 2013).

이 도입될 시, 고품질의 재생 시멘트를 제조할 수 있을 것으로 사료된다.

폐콘크리트 미분말을 재생 시멘트로 이용하기 위해서 는 시멘트의 수화반응 및 고화체의 초기 강도에 중요한 영향을 미치는 $\beta-\mathrm{C}_{2} \mathrm{~S}, \mathrm{C}_{3} \mathrm{~S}$ 와 같은 주요 화합물이 존재하 여야 하며, 이러한 주요 화합물은 소성 과정을 거침에 따 라 식 (3)-(4)와 같은 열분해 반응에 의하여 생성될 수 있 다(Qin and Gao, 2019; Qin and Gao, 2019).

$\mathrm{Ca}(\mathrm{OH})_{2} \longrightarrow \mathrm{CaO}_{(s)}+\mathrm{H}_{2} \mathrm{O}_{(\mathrm{g})}$

$2 \mathrm{CaO}+\mathrm{SiO}_{2} \longrightarrow 2 \mathrm{CaO} \cdot \mathrm{SiO}_{2}\left(\beta-\mathrm{C}_{2} \mathrm{~S}\right)$ 
Mun et al. (2017)은 소성하지 않은 폐콘크리트 미분말 내 $\mathrm{Ca}$ 는 $\mathrm{Ca}(\mathrm{OH})_{2}$ 의 형태로 존재하나, $500^{\circ} \mathrm{C}$ 이상의 소 성 조건에서는 열 분해반응에 의한 $\mathrm{Ca}(\mathrm{OH})_{2}$ 의 형태가 현 저히 감소하는 것을 확인하였다. 또한, $600^{\circ} \mathrm{C}$ 이상의 소 성 조건에서는 방해석 $\left(\mathrm{Calcite}, \mathrm{CaCO}_{3}\right)$ 의 탈탄산반응에 의 하여 생석회(lime, $\mathrm{CaO}$ )가 생성되며, $900^{\circ} \mathrm{C}$ 이상의 소성 조건에서는 대부분의 방해석이 생석회의 형태로 변환되

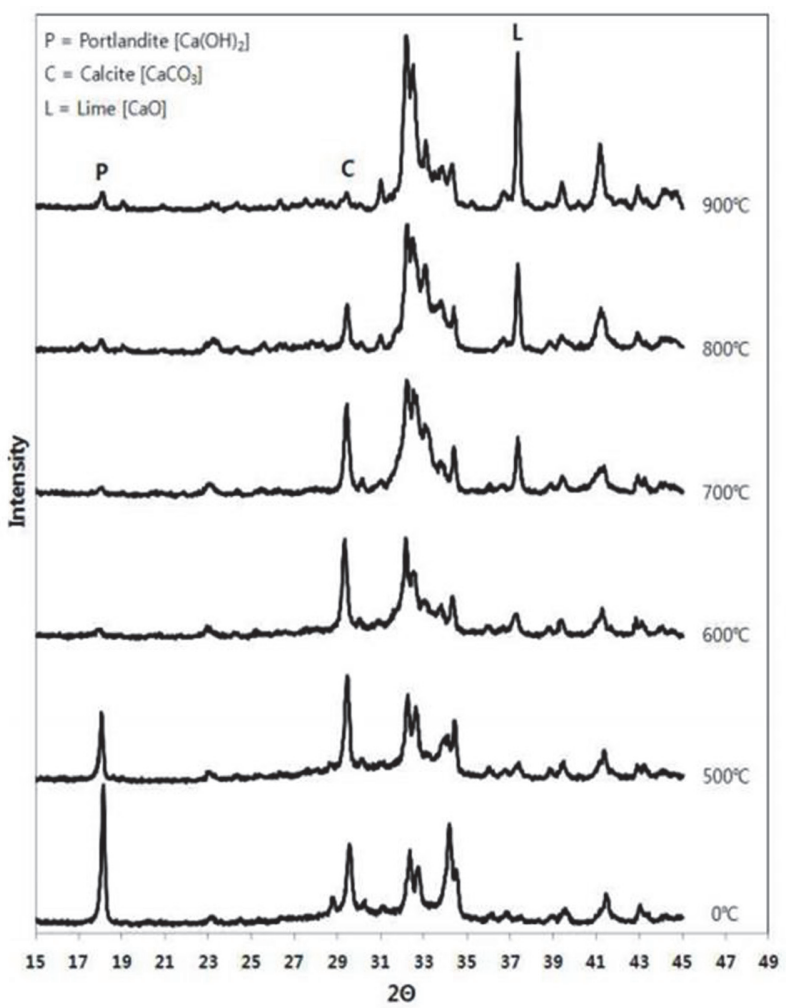

Fig. 2. XRD analysis results of waste concrete powder before and after sintering (data from Mun et al., 2017).

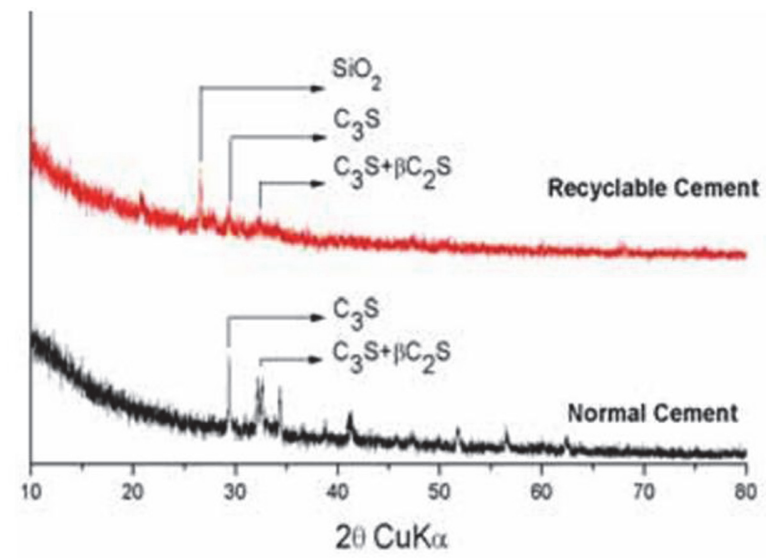

Fig. 3. XRD analysis results of recycling cement and normal cement (data from Oh et al., 2005).
는 것을 확인하였다(Fig. 2). Oh (2005)은 $700^{\circ} \mathrm{C}$ 로 소성 한 일반 포틀랜드 시멘트와 재생 시멘트 모두 시멘트 수 화반응의 주요 화합물인 $\beta-\mathrm{C}_{2} \mathrm{~S}, \mathrm{C}_{3} \mathrm{~S}$ 가 생성되는 것을 확 인하였으며, 재생 시멘트의 경우 잔골재의 혼입에 따라 $\mathrm{SiO}_{2}$ 의 피크가 일반 포틀랜드 시멘트보다 높게 나타난 것 을 확인하였다(Fig. 3). 이를 통하여, 폐콘크리트의 미분 말을 재생 시멘트로서 이용이 가능함을 알 수 있으며, $\mathrm{CaO}$ 의 생성이 확연하게 나타나기 시작하는 $700^{\circ} \mathrm{C}$ 로 소 성할 경우 폐콘크리트 미분말을 이용한 재생 시멘트의 제조가 가능한 것으로 사료된다.

\section{2. 폐콘크리트를 이용한 고화체 특성}

폐콘크리트 미분말을 이용한 모르타르 유동성은 유리 석회의 소화에 의한 분화 현상이 일어남에 따라 산업부 산물을 혼합한 재생 시멘트에 비하여 낮게 나타났으며, 고로슬래그, 비산회를 혼합할 경우 유리석회 감소 등의 효과로 인해 유동성이 개선되는 것을 확인하였다(Kang et al., 2011). 이러한 이유는 폐콘크리트 미분말에 혼합 된 잔골재 표면의 미세균열 및 표면에 부착된 페이스트 에 의하여 유동성이 저하되는 것으로 판단된다 $(\mathrm{Lim} e t$ al., 2007). 그러나, 폐콘크리트 미분말을 이용한 모르타 르 유동성에 대한 연구는 거의 수행되지 않음에 따라 추 가적인 연구가 필요한 실정이다.

폐콘크리트 미분말을 재생 시멘트 제조를 위한 고화재 로 이용할 경우, 원전 해체로 인하여 발생되는 방사성 폐 기물 발생량 및 처분 비용을 저감 할 수 있다. 그러나, 폐 콘크리트 미분말을 재생 시멘트로 이용한 고화체의 경우 폐콘크리트 미분말 내 혼입된 잔골재 성분으로 인하여 고화체 압축강도 인수기준 $3.44 \mathrm{MPa}$ 를 만족하기 어려우 며, 방사성 폐기물을 담지할 경우 고화체의 강도는 더욱 감소할 것으로 생각된다(Kim et al., 2013; Ye et al., 2020). Ahn et al. (2013)은 폐콘크리트 미분말 내 잔골재 혼합 율이 증가함에 따라 재생 시멘트의 강도가 크게 저하되 는 것을 확인하였으며, 이는 잔골재의 혼입에 의한 재생 시멘트의 수화성 회복에 영향을 미치는 $\mathrm{CaO}$ 함량이 감 소하기 때문인 것으로 판단된다(Fig. 4). 이러한 문제에 따라 고로슬래그, 비산회와 같은 산업부산물을 성분조정 재로 첨가하거나 일반 포틀랜드 시멘트와의 배합을 통하 여 고화체의 특성을 개선하는 방법이 이용되고 있다( $\mathrm{Lim}$ et al., 2007). 본 절에서는 재생 시멘트 고화체의 고화재 로 폐콘크리트 미분말을 단일로 사용하거나, 일반 포틀 랜드 시멘트와 배합한 고화체의 특성에 대하여 알아보았 으며, 폐콘크리트 미분말과 산업부산물을 첨가제로 이용 한 고화체의 특성은 3절에서 제시하고자 한다.

기존 문헌 조사를 통하여 폐콘크리트 미분말을 재생 시 


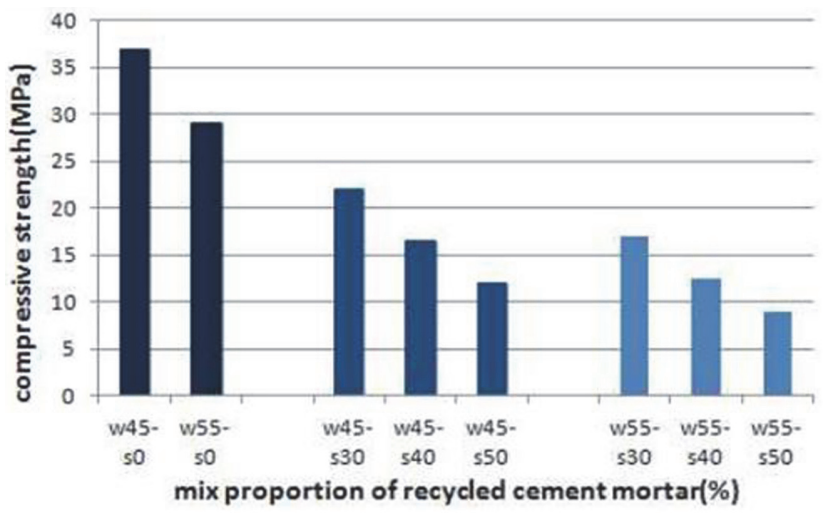

Fig. 4. Variation in the compressive strength of recycling cement according to the mixing rate of fine aggregates in the waste concrete powder (data from Ahn et al., 2013).

멘트로 이용하여 제조한 고화체에 대하여 배합비에 따른 압축강도를 Table 2에 정리하였다. 폐콘크리트 미분말을 단일로 이용한 연구에서 재생 시멘트의 압축강도는 고화 체 인수기준인 $3.44 \mathrm{MPa}$ 보다 낮은 것으로 나타났다(Min et al., 2009; Ahn and Park, 2013; Mun et al., 2017). 그 러나, Mun et al. (2017)의 연구에서는 압축강도가 양생

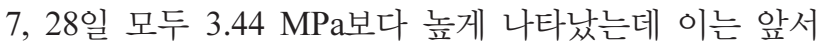
2.1절에서 제시한 바와 같이 폐콘크리트의 구성 성분 및
잔골재의 혼입에 따라 압축강도가 달라질 수 있음을 의 미한다. 또한, Ahn et al. (2013)은 앞선 선행연구에서 재 생 시멘트의 압축강도는 $700^{\circ} \mathrm{C}$ 의 소성 온도에서 최적의 효율을 낼 수 있음을 확인하였으나, Mun et al. (2017)은 $600^{\circ} \mathrm{C}$ 의 소성 온도에서의 압축강도가 $700^{\circ} \mathrm{C}$ 의 소성 온 도보다 약 $10 \mathrm{MPa}$ 높게 나타남에 따라 최적의 소성 온 도 조건은 $600^{\circ} \mathrm{C}$ 로 제시하였다.

Min et al. (2009)은 폐콘크리트 미분말을 고화재로 이 용한 재생 시멘트로 코발트 $(\mathrm{Co})$ 와 세슘 $(\mathrm{Cs})$ 을 담지한 고 화체를 제조한 후 침출 특성을 평가하기 위하여, 단기적 침출 시험법인 $\mathrm{ANS} 16.1$ 시험법에 따라 실험을 수행하 였으며, 식 (5)를 이용하여 $\mathrm{Co}, \mathrm{Cs}$ 의 침출 지수를 도출하였다.

$$
L_{i}=\frac{1}{k} \sum_{n=1}^{k}\left[\log \left(\beta / D_{e}\right)\right]_{n}
$$

$\mathrm{L}_{\mathrm{i}}$ : Leachability index

$\mathrm{D}_{\mathrm{e}}$ : Effective diffusion coefficient

$\mathrm{k}$ : Number of times in which the leachant was changed $\beta$ : a defined constant, $1.0 \mathrm{~cm}^{2} / \mathrm{sec}$

방사성 핵종 침출 지수는 유효 확산계수 $\left(\mathrm{D}_{\mathrm{e}}\right)$ 가 분모에 있어 유효 확산계수가 낮을수록 침출 지수가 증가하게 되어 처분장 인수 기준치인 6 이상의 값일수록 방사성

Table 2. The compressive strength of recycling cement according to the mixing ratio of several materials

\begin{tabular}{|c|c|c|c|c|c|c|c|c|c|c|}
\hline \multirow{2}{*}{$\begin{array}{l}\text { Sintering } \\
\text { temperature } \\
\left({ }^{\circ} \mathrm{C}\right)\end{array}$} & \multirow{2}{*}{$\begin{array}{l}\text { Sintering } \\
\text { duration } \\
\text { (h) }\end{array}$} & \multicolumn{5}{|c|}{ Mixing ratio (wt\%) } & \multirow{2}{*}{$\begin{array}{l}\mathrm{W} / \mathrm{B} \\
\text { (Water/ } \\
\text { Binder } \\
\text { ratio) }\end{array}$} & \multicolumn{2}{|c|}{$\begin{array}{l}\text { Compressive } \\
\text { strength }(\mathrm{MPa})\end{array}$} & \multirow{2}{*}{ References } \\
\hline & & $\begin{array}{l}\text { Waste concrete } \\
\text { powder }\end{array}$ & $\begin{array}{c}\text { Portland } \\
\text { cement }\end{array}$ & $\begin{array}{c}\text { Fine } \\
\text { aggregate }\end{array}$ & Gypsum & $\begin{array}{l}\text { Sodium } \\
\text { silicate }\end{array}$ & & $\begin{array}{l}7 \text {-day } \\
\text { curing }\end{array}$ & $\begin{array}{l}\text { 28-day } \\
\text { curing }\end{array}$ & \\
\hline \multirow{2}{*}{700} & \multirow{2}{*}{2} & 90 & - & & - & 10 & \multirow{2}{*}{0.6} & \multirow{2}{*}{-} & 2.0 & \multirow{2}{*}{$\begin{array}{l}\text { Min et al., } \\
2009\end{array}$} \\
\hline & & 80 & 10 & & - & 10 & & & 3.6 & \\
\hline 700 & 1 & 97 & - & - & 3 & - & 0.6 & 2.0 & 1.5 & $\begin{array}{c}\text { Ahn and Park, } \\
2013\end{array}$ \\
\hline \multirow{4}{*}{ - } & \multirow{4}{*}{-} & 30 & \multirow{4}{*}{10} & 45 & \multirow{4}{*}{-} & \multirow{4}{*}{-} & \multirow{4}{*}{$\begin{array}{l}\text { Water } \\
15 \\
w t \%\end{array}$} & \multirow{4}{*}{ - } & 4.3 & \multirow{4}{*}{$\begin{array}{l}\text { Lee et al., } \\
2013\end{array}$} \\
\hline & & 22.5 & & 52.5 & & & & & 5.0 & \\
\hline & & 15 & & 60 & & & & & 4.3 & \\
\hline & & 7.5 & & 67.5 & & & & & 5.2 & \\
\hline 0 & \multirow{6}{*}{ - } & \multirow{6}{*}{96} & \multirow{6}{*}{ - } & \multirow{6}{*}{-} & \multirow{6}{*}{4} & \multirow{6}{*}{-} & \multirow{6}{*}{0.6} & 6.1 & 10.8 & \multirow{6}{*}{$\begin{array}{c}\text { Mun et al., } \\
2017\end{array}$} \\
\hline 500 & & & & & & & & 15.0 & 22.0 & \\
\hline 600 & & & & & & & & 21.3 & 30.8 & \\
\hline 700 & & & & & & & & 14.9 & 19.9 & \\
\hline 800 & & & & & & & & 1.9 & 20.3 & \\
\hline 900 & & & & & & & & 5.9 & 14.7 & \\
\hline \multirow{3}{*}{-} & \multirow{3}{*}{-} & & 33 & 67 & - & - & \multirow{3}{*}{0.6} & \multirow{3}{*}{-} & 12.2 & \multirow{3}{*}{$\begin{array}{l}\text { Koo et al., } \\
\quad 2018\end{array}$} \\
\hline & & & 36 & 64 & & & & & 12.5 & \\
\hline & & - & 38 & 62 & - & - & & & 17.2 & \\
\hline
\end{tabular}


핵종의 침출이 감소하는 것을 의미한다. 방사성 핵종의 침출 지수는 폐콘크리트 미분말의 조성과 상관없이 거의 동일하였으며, 처분장 최소 인수 기준치인 6 이상으로 나 타났으며, $\mathrm{Co}$ 는 인수 기준치의 2 배 이상의 값으로 나타 났다. 이를 통하여, 폐콘크리트 미분말을 재생 시멘트로 이용한 고화체의 침출 지수는 방사성 핵종에 대한 권고 치를 만족시킴에 따라 재생 시멘트로서 활용 가능한 것 을 확인하였다.

Lee et al. (2013)은 콘크리트 폐기물, 물, 시멘트의 배 합비 75:15:10 wt\%의 비율로 제조한 고화체 시편을 이 용한 열 순환 시험을 평가하였다. 열 순환 실험 후, 고화 체의 무게는 감소하였으나, 다른 물리적인 변화는 관측 되지 않았다. 또한, 압축강도는 열 순환 시험 이전보다 상승하는 결과로 나타남에 따라 폐콘크리트 미분말을 이 용한 재생 시멘트의 경우 열저항 특성이 우수함을 확인 하였다.

이러한 기존 연구를 통하여 폐콘크리트 미분말을 재생 시멘트로 이용할 수 있음을 알 수 있었다. 그러나, 재생 시멘트의 압축강도는 연구에 사용된 폐콘크리트 미분말 및 잔골재의 화학적 성분 차이, 잔골재의 혼입 등과 같 은 원인에 의하여 변할 수 있음에 따라 재생 시멘트로서 활용 가능성에 대한 정확한 평가가 어렵다. 또한, 방사성 폐기물 처리 소재로 사용하기 위하여 침출 시험, 열 순 환 시험과 같은 고화체 특성 평가에 대한 연구는 아직까 지 부족한 실정이며, 추가적인 연구가 필요한 것으로 생 각된다.

\section{3. 폐콘크리트와 산업부산물을 이용한 재생 시 멘트 활용 가능성}

앞서 2장에서 폐콘크리트 미분말을 재생 시멘트로 재 활용이 가능한 것을 확인하였으나, 폐콘크리트 미분말, 잔골재의 화학적 성분 차이, 잔골재의 혼입과 같은 원인 에 의하여 고화체의 특성이 저하되는 것을 확인하였다. 이러한 이유로 재생 시멘트의 성능을 증진시키기 위하여 산업 부산물인 고로슬래그와 비산회를 첨가제로 사용한 연구가 활발히 수행되어왔으며, 산업부산물을 혼합한 콘 크리트의 사용이 많아질 것으로 생각된다(Park and Kang, 2004; El-Kamash et al., 2006; Cinquepalmi et al., 2008; Jang et al., 2013). 고로슬래그 미분말을 이용한 콘크리 트의 경우 시공성 및 수축 등의 문제가 지적되어왔으나 (Yang and Song, 2007), 상온에서 강도 발현이 우수하여 40-70 MPa의 압축강도를 가지는 고화체의 제조가 가능 한 장점이 있다(Collins and Sanjayan, 2000). 또한, 고로 슬래그 미분말은 모르타르 유동성 증가, 고화체 장기적
강도 증진, 수화열에 의한 온도 상승 억제 등의 효과를 나타낸다(Koh et al., 2010). 비산회를 이용한 경우, 고화 체 장기적 강도 증진, 수화열 감소, 내구성 향상 등의 효 과를 나타낼 수 있으나(Nam, 2010; Lee, 2011), 상온에서 강도 발현의 어려움, 중합반응 활성화를 위한 고온 양생 이 필요한 단점이 있다(Jo et al., 2006).

폐콘크리트 미분말과 산업부산물을 이용한 고품질의 재생 시멘트 및 고화체를 제조하기 위하여 각 물질에 대 한 기초 특성, 배합 비율에 따른 고화체의 유동성, 압축 강도 등을 평가하여 최적의 배합비와 같은 기초자료를 명확하게 확립하는 것이 중요할 것으로 생각된다.

3장에서는 기존에 수행된 문헌들을 통하여 폐콘크리트 미분말을 산업부산물인 고로슬래그, 비산회를 혼합하여 고품질의 재생 시멘트로 재활용하기 위하여 (1) 고로슬 래그, 비산회의 주요 화학적 및 광물학적 특성에 대하여 알아보았으며, (2) 폐콘크리트 미분말과 고로슬래그, 비 산회를 혼합하여 제조한 고화체의 모르타르 유동성, 압 축강도 등에 대하여 알아보았다.

\section{1. 폐콘크리트와 산업부산물을 이용한 재생 시멘트의 기초 특성}

폐콘크리트 미분말을 이용한 재생 시멘트는 잔골재의 혼입에 따라 $\mathrm{Ca}$ 함량이 감소하게 되며, $\mathrm{Si}$ 성분은 주로 석영으로 존재함에 따라 시멘트의 수화반응에 주요한 영 향을 미치는 $\beta-\mathrm{C}_{2} \mathrm{~S}, \mathrm{C}_{3} \mathrm{~S}$ 와 같은 주요 화합물 함량이 매 우 낮다(Oh and Hong, 2007). 이러한 이유로 $\mathrm{Ca}$ 와 $\mathrm{Si}$ 를 보충하기 위하여 산업부산물인 고로슬래그와 비산회를 첨가하여 재생 시멘트의 품질을 향상시킬 수 있는 것으 로 기대되어 기존 문헌 조사를 통한 고로슬래그와 비산 회의 화학적 성분을 Table 3 에 정리하였다. 고로슬래그의 주성분은 $\mathrm{CaO}, \mathrm{SiO}_{2}, \mathrm{Al}_{2} \mathrm{O}_{3}$ 로 나타났으며, 모든 문헌에 서 $\mathrm{CaO}$ 는 $40 \mathrm{wt} \%$ 이상의 함량을 나타냄에 따라 폐콘크 리트 미분말의 낮은 $\mathrm{CaO}$ 함량을 보완할 수 있으며, 시멘 트의 수화반응을 증진시켜 고화체의 압축강도를 높일 수 있을 것으로 생각된다. 비산회의 주성분은 $\mathrm{SiO}_{2}, \mathrm{Al}_{2} \mathrm{O}_{3}$ 로 각 평균 함량은 $52.8,29.9 \mathrm{wt} \%$ 로 반응성 산화물이 다량 포함되어 있는 것으로 나타났으며, 알칼리 활성제의 사 용 및 고온 양생 등에 의하여 $\mathrm{Al}-\mathrm{Si}$ 중합반응을 통한 콘 크리트의 강도 발현을 일으킬 수 있을 것으로 판단된다 (Palomo et al., 1999).

Ahn et al. (2013)은 폐콘크리트 미분말과 산업부산물 인 고로슬래그, 비산회를 혼합한 재생 시멘트에 대한 광 물학적 분석을 수행하였다. 폐콘크리트 미분말은 시멘트 수화반응을 일으키는 주요 화합물인 $\beta-\mathrm{C}_{2} \mathrm{~S}$ 의 피크가 낮 게 나타났으나, 고로슬래그를 혼합한 재생 시멘트에서 $\beta$ - 
Table 3. The chemical properties of blast furnance slag and fly ash

\begin{tabular}{|c|c|c|c|c|c|c|c|c|c|c|c|}
\hline \multirow{2}{*}{ Type } & \multicolumn{10}{|c|}{ Chemical composition (unit: wt $\%$ ) } & \multirow{2}{*}{ References } \\
\hline & $\mathrm{CaO}$ & $\mathrm{SiO}_{2}$ & $\mathrm{Al}_{2} \mathrm{O}_{3}$ & $\mathrm{Fe}_{2} \mathrm{O}_{3}$ & $\mathrm{MgO}$ & $\mathrm{MnO}$ & $\mathrm{Na}_{2} \mathrm{O}$ & $\mathrm{K}_{2} \mathrm{O}$ & Others & LOI & \\
\hline \multirow{7}{*}{$\begin{array}{c}\text { Blast } \\
\text { furnace slag }\end{array}$} & 41.8 & 33.5 & 13.6 & 0.4 & 6.4 & 0.5 & - & - & 2.3 & - & Park et al., 2007 \\
\hline & 42.1 & 33.3 & 15.3 & 0.4 & 5.7 & - & - & - & 2.1 & 0.03 & Koh et al., 2010 \\
\hline & 42.4 & 33.1 & 13.8 & 0.29 & 6.1 & 0.4 & 0.23 & 0.31 & 0.67 & - & Kang et al., 2011 \\
\hline & 44.6 & 34.7 & 13.8 & 0.1 & 4.4 & 0.2 & - & 0.5 & 1.7 & - & Kim et al., 2012 \\
\hline & 46.2 & 32.7 & 13.0 & 0.5 & 3.0 & 0.3 & 0.2 & 0.5 & 1.0 & - & Jang et al., 2013 \\
\hline & 43.5 & 35.2 & 16.5 & 0.5 & 3.5 & - & - & - & 0.8 & - & Lee et al., 2015 \\
\hline & 43.3 & 31.2 & 11.4 & 0.5 & 7.4 & - & 0.2 & 0.4 & 4.1 & - & Hwang et al., 2018 \\
\hline \multirow{7}{*}{ Fly ash } & 6.1 & 58.8 & 22.5 & 5.6 & 1.7 & - & - & 0.9 & - & - & Jung et al., 1998 \\
\hline & 3.0 & 49.6 & 31.9 & 5.9 & 0.9 & 0.1 & 0.4 & 0.9 & 2.6 & 4.3 & Park et al., 2007 \\
\hline & 3.0 & 49.6 & 31.9 & 5.9 & 1.0 & 0.1 & 0.4 & 0.9 & 2.5 & 4.3 & Kang et al., 2008 \\
\hline & 3.2 & 52.0 & 23.8 & 4.3 & 0.9 & - & 0.7 & 0.9 & 1.0 & - & Yeon et al., 2008 \\
\hline & 2.9 & 55.3 & 25.8 & 5.5 & 0.8 & - & - & - & 0.3 & 3.2 & Koh et al., 2010 \\
\hline & 1.7 & 59.9 & 27.9 & 4.6 & 1.1 & - & 2.6 & 0.7 & - & 3.8 & Kang et al., 2011 \\
\hline & 2.3 & 44.6 & 46.1 & 2.0 & 0.8 & - & 2.0 & - & - & - & Tian and Sasaki, 2019 \\
\hline
\end{tabular}

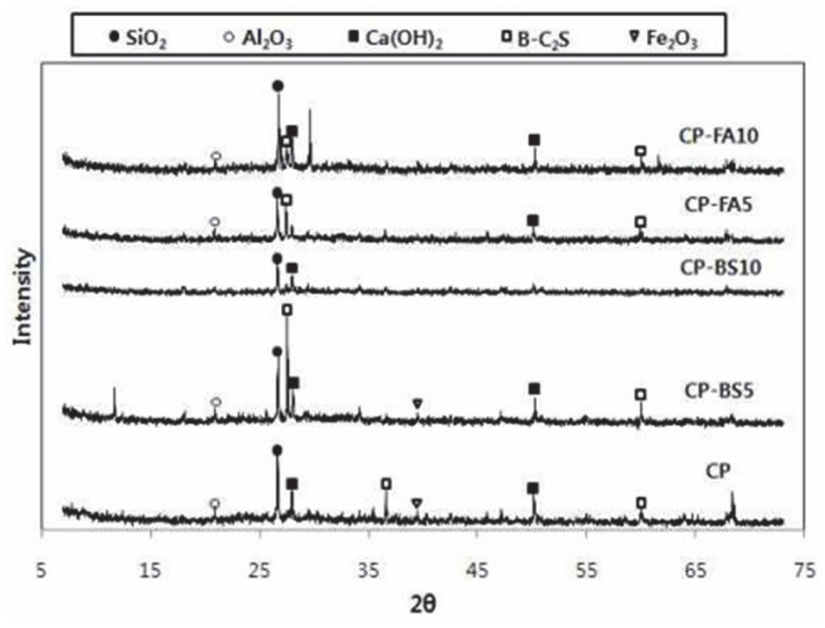

Fig. 5. XRD analysis results of recycling cement mixed with waste concrete powder and industrial by-products (data from Ahn et al., 2013).

$\mathrm{C}_{2} \mathrm{~S}$ 의 피크가 증가하는 것을 확인하였다. 그러나, 비산회 를 혼합한 재생 시멘트는 $\beta-\mathrm{C}_{2} \mathrm{~S}$ 의 피크가 증가하였으나, 고로슬래그에 비하여 매우 낮은 증가폭으로 나타남을 확 인하였다(Fig. 5).

이러한 선행연구들을 통하여, 산업부산물인 고로슬래 그와 비산회를 폐콘크리트 미분말과 혼합하여 재생 시멘 트를 제조할 시, 고성능의 재생 시멘트를 제조할 수 있 음을 확인하였으며, 고로슬래그가 비산회보다 시멘트의 강도 발현에 더욱 큰 영향을 미칠 수 있을 것으로 판단된다.

\section{2. 폐콘크리트와 산업부산물을 이용한 고화체 특성}

재생 시멘트 모르타르의 물성으로, 모르타르 유동성은 폐콘크리트 미분말과 산업부산물인 고로슬래그, 비산회 를 혼합한 재생 시멘트에서 $\beta-\mathrm{C}_{2} \mathrm{~S}$ 등의 생성으로 인한 유리석회의 감소 효과로 인해 유동성 개선이 나타났다 (Ahn and Park, 2013). 또한, 고로슬래그와 비산회의 혼 합율이 증가할수록 유동성이 증진되는 것을 확인하였으 며, 산업부산물의 종류에 따른 변화는 크지 않은 것을 확 인하였다(Kang et al., 2011). 그러나, Koh et al. (2010) 은 비산회의 혼합율이 높을 때, 모르타르 유동성이 높은 것을 확인하였으며, 고로슬래그의 경우 알칼리 활성제와 의 빠른 반응을 통한 급결이 일어나 유동성이 감소하는 것을 확인하였다.

기존 문헌조사를 통하여 폐콘크리트 미분말과 고로슬 래그, 비산회를 혼합하여 제조한 고화체에 대하여 배합 비에 따른 압축강도를 Table 4에 정리하였다. Ahn et al. (2013)의 연구에서 폐콘크리트 미분말과 고로슬래그, 비 산회를 혼합한 재생 시멘트의 압축강도는 폐콘크리트 미 분말을 단일로 이용할 때 보다 증진되며, 양생 91일 이 후 모든 고화체에서 인수기준 $3.44 \mathrm{MPa}$ 를 만족하는 것 을 확인하였다. 또한, 고로슬래그는 높은 $\mathrm{CaO}$ 함량을 가 짐에 따라 시멘트 수화반응이 더욱 증진되어 압축강도가 비산회를 혼합한 고화체보다 높게 나타난 것으로 생각된 다. Koh et al. (2010)은 산업부산물인 고로슬래그와 비 산회 미분말을 이용한 무시멘트 모르터의 유동성과 강도 특성에 대하여 고찰하였다. 비산회를 이용한 경우 시간 
Table 4. The compressive strength of solidified matrix according to the mixing ratio of waste concrete powder, blast furnance slag, and fly ash

\begin{tabular}{|c|c|c|c|c|c|c|c|c|c|c|c|}
\hline \multirow{2}{*}{$\begin{array}{c}\text { Sintering } \\
\text { temperature } \\
\left({ }^{\circ} \mathrm{C}\right)\end{array}$} & \multirow{2}{*}{$\begin{array}{l}\text { Sintering } \\
\text { duration } \\
\text { (h) }\end{array}$} & \multicolumn{5}{|c|}{ Mixing ratio $(\mathrm{wt} \%)$} & \multirow{2}{*}{$\begin{array}{l}\text { W/B } \\
\text { (Water/ } \\
\text { Binder } \\
\text { ratio) }\end{array}$} & \multicolumn{3}{|c|}{ Compressive strength $(\mathrm{MPa})$} & \multirow[b]{2}{*}{ References } \\
\hline & & $\begin{array}{c}\text { Waste } \\
\text { concrete } \\
\text { powder }\end{array}$ & $\begin{array}{c}\text { Portland } \\
\text { cement }\end{array}$ & $\begin{array}{c}\text { Blast } \\
\text { furnace } \\
\text { slag }\end{array}$ & $\begin{array}{l}\text { Fly } \\
\text { ash }\end{array}$ & Gypsum & & $\begin{array}{l}\text { 7-day } \\
\text { curing }\end{array}$ & $\begin{array}{l}\text { 28-day } \\
\text { curing }\end{array}$ & $\begin{array}{l}\text { 91-day } \\
\text { curing }\end{array}$ & \\
\hline \multirow{5}{*}{700} & \multirow{5}{*}{1} & 97 & - & - & - & \multirow{5}{*}{3} & \multirow{5}{*}{0.6} & 2.0 & 1.5 & 3.3 & \multirow{5}{*}{$\begin{array}{c}\text { Ahn and Park, } \\
2013\end{array}$} \\
\hline & & 92 & - & 5 & - & & & 2.9 & 5.1 & 6.2 & \\
\hline & & 92 & - & - & 5 & & & 1.0 & 2.2 & 4.5 & \\
\hline & & 87 & - & 10 & - & & & 3.9 & 6.1 & 7.7 & \\
\hline & & 87 & - & - & 10 & & & 2.2 & 3.2 & 4.8 & \\
\hline \multirow{6}{*}{600} & \multirow{2}{*}{1} & \multirow{12}{*}{76} & & 20 & - & \multirow{12}{*}{4} & \multirow{12}{*}{0.6} & 2.4 & 4.6 & & \\
\hline & & & & - & 20 & & & 2.2 & 4.7 & & \\
\hline & 15 & & & 20 & - & & & 3.0 & 4.3 & & \\
\hline & 1.5 & & & - & 20 & & & 3.5 & 4.9 & & \\
\hline & 0 & & & 20 & - & & & 3.6 & 8.3 & & \\
\hline & 2 & & & - & 20 & & & 3.2 & 5.4 & & Park and Kang, \\
\hline \multirow{6}{*}{700} & \multirow{2}{*}{1} & & - & 20 & - & & & 3.0 & 6.6 & - & 2004 \\
\hline & & & & - & 20 & & & 4.4 & 5.6 & & \\
\hline & \multirow{2}{*}{1.5} & & & 20 & - & & & 3.3 & 8.0 & & \\
\hline & & & & - & 20 & & & 3.4 & 6.1 & & \\
\hline & \multirow{2}{*}{2} & & & 20 & - & & & 2.6 & 8.0 & & \\
\hline & & & & - & 20 & & & 3.3 & 7.4 & & \\
\hline
\end{tabular}

에 따른 유동성 변화는 없었으나, 압축강도가 발현되지 않았으며, 고로슬래그를 이용하였을 때, 유동성의 저하가 일어나지만 압축강도는 $50 \mathrm{MPa}$ 이상으로 나타났다. 이 러한 문제점을 상쇄하고자 비산회, 고로슬래그의 배합비 에 따른 연구 결과 비산회, 고로슬래그 50:50의 배합비에 서 유동성의 저하가 감소되고, 압축강도가 $70 \mathrm{MPa}$ 이상 으로 증진되는 효과를 확인할 수 있었다. Park and Kang (2004)은 폐콘크리트 미분말과 고로슬래그, 비산회를 혼 합한 재생 시멘트의 압축강도 평가에 있어 소성 온도, 소 성 시간에 따른 변화를 고찰하였다. 고로슬래그와 비산 회의 배합에 따른 강도는 큰 차이가 없는 것을 확인하였 다. 그러나, 소성 온도의 증가 및 소성 시간이 증가함에 따라 고로슬래그를 혼합한 고화체의 압축강도가 증진되 는 것을 확인하였다. 이는 소성 온도 $600^{\circ} \mathrm{C}$ 에서보다 $700^{\circ} \mathrm{C}$ 의 조건에서 시멘트 수화 반응물인 $\beta-\mathrm{C}_{2} \mathrm{~S}$ 의 생성이 더욱 활발히 일어남에 따라 고화체의 압축강도가 증진된 것으 로 생각된다. 따라서 폐콘크리트 미분말과 고로슬래그, 비산회를 혼합한 고성능 재생 시멘트를 제조하기 위한 최적의 소성 온도 및 시간은 $700^{\circ} \mathrm{C}, 90$ 분으로 판단된다.

기존 연구를 통하여 폐콘크리트 미분말과 산업부산물 인 고로슬래그, 비산회를 혼합할 경우 고성능의 재생 시 멘트로 이용할 수 있음을 알 수 있었다. 그러나, 현재까
지 수행된 연구는 재생 시멘트의 재활용 가능성에 대한 평가만 이루어졌으며, 방사성 폐기물 처리 소재로 사용 하기 위한 평가는 전혀 이루어지지 않았다. 따라서 이러 한 고성능의 재생 시멘트를 이용한 방사성 폐기물 처리 를 위해서는 방사성 핵종을 담지한 고화체를 제조하고 압축강도, 침출, 열 순환 시험과 같은 고화체 특성을 평 가하는 연구가 추가적으로 필요할 것으로 생각된다.

\section{4. 폐토양 내 점토 광물을 이용한 비소성 시멘트}

원자력 시설 해체 시 발생되는 폐기물은 폐콘크리트, 폐토양 등이 발생된다. 폐콘크리트의 경우 재생 시멘트 로 재활용할 수 있으며, 고로슬래그, 비산회와 같은 산업 부산물을 혼합한 고강도, 고성능 재생시멘트의 제조에 관 한 연구가 현재까지 활발히 수행되고 있음을 앞서 제시 하였다. 그러나, 폐토양은 실트 및 점토에 $\mathrm{Co}, \mathrm{Cs}$ 와 같은 방사성 핵종의 흡착성능이 우수한 illite, zeolite와 같은 점토 광물이 있음에도 불구하고 비소성 시멘트로 활용한 연구가 현재까지 수행된 바 없으며, 점토 광물을 이용한 방사성 핵종의 흡착에 관한 연구만 수행되었다(Cheon et al., 2014; Kim et al., 2016; Hwang et al., 2018).

점토 광물을 이용한 비소성 시멘트의 제조는 연구적 관 
점에서 수행된 바 없으며, 특허를 인용하여 일라이트와 시멘트, 산업부산물을 혼합한 비소성 시멘트의 제조 및 활용 가능성에 대하여 간략하게 설명하고자 한다. Im et al. (2016)은 일라이트 및 고로슬래그, 제올라이트와 같은 혼화재를 혼합하여 비소성 시멘트를 제조할 수 있음을 제시하였다. 그러나, 본 발명에 사용된 일라이트의 함량 은 3-5\%로 매우 적으며, 고화체의 압축강도, 침출 등에 대한 자료를 제시하지 않음에 따라 비소성 시멘트로서 활용 가능성을 평가할 수 없다.

본 연구에서 제시하고자 하는 목적과는 다소 부합되지 않지만 향후 폐토양을 이용한 비소성 시멘트 제조에 있 어 혼합물의 기초자료를 제시하고자 산업부산물을 이용 한 비소성 시멘트의 제조 및 활용 가능성을 평가한 연구 에 대하여 간략히 설명하고자 한다. Choi et al. (2020)은 산업부산물인 고로슬래그와 비산회를 이용한 비소성 시 멘트를 제조하여 일반 포틀랜드 시멘트와 비교 평가하였 다. 고로슬래그와 비산회를 이용한 비소성 시멘트의 압 축강도는 재령 $3,7,28$ 일 각 $13.7,15.6,18.9 \mathrm{MPa}$ 로 나 타남에 따라 재생시멘트로서 활용 가능함을 알 수 있다.

전 세계적으로 노후화된 원자력 시설의 해체 시장은 급 격하게 부상하고 있으며, 발생 폐기물은 콘크리트, 토양, 금속 등 종류가 다양할 뿐만 아니라 발생량 또한 방대하 다(Song, 2016). 원전 해체 폐기물인 폐콘크리트의 재활 용 방안에 대한 연구는 지속적으로 수행되어 왔으나, 중 ·저준위 폐토양을 재활용하는 방안에 대한 직접적인 연 구는 수행되지 않았다. 폐토양 내 일라이트는 세슘 흡착 능이 우수하며, 제올라이트와 함께 핵종을 흡착할 수 있 다(Kim et al., 2016). 이러한 이유에서 폐토양 내 점토 광물을 이용한 방사성 핵종의 고화 처리 시, 다른 흡착 제를 사용하지 않아도 방사성 폐기물에 함유되어 있는 핵종의 흡착능을 증가시켜 안전하게 처분할 수 있을 것 으로 생각된다. 또한, 원전 해체 폐기물인 중·저준위 폐 토양 내 일라이트와 제올라이트를 원전 해체 폐기물인 굵은 골재, 산업부산물인 고로슬래그, 비산회와 같이 혼 합하여 비소성 시멘트를 제조할 경우, 원전 해체 폐기물 을 줄임과 동시에 방사성 폐기물을 담지할 수 있는 효과 를 도출시킬 수 있을 것으로 판단된다. 이러한 이유에서 점토 광물을 이용한 비소성 시멘트의 제조에 대한 연구 가 수행되어야 한다고 생각된다.

\section{5. 시사점 및 제언}

국내외적으로 원자력 시설의 해체는 증가하고 있으며, 방대한 양의 콘크리트, 금속, 토양 등의 폐기물이 발생한 다. 이러한 이유에서, 폐기물 감용 및 재활용 기술의 확
보는 매우 중요한 문제로 대두되고 있다. 원전 해체 폐 기물 중 $60-80 \%$ 를 차지하는 콘크리트 폐기물은 골재와 페이스트를 분리하여 사용할 수 있으며, 순환 골재 생산 과정에서 발생되는 시멘트 페이스트와 잔골재 미분과 같 은 폐미분말을 고화재로 재활용한 연구는 지속적으로 수 행되어 왔다. 폐미분말을 재생 시멘트로 재활용한 고화 체는 처분장 인수기준 $3.44 \mathrm{MPa}$ 를 만족하지 못하였으나, 폐미분말 내 잔골재의 혼입이 최소화될 경우, 압축강도 인수기준 이상의 값을 만족하는 것이 입증되었다. 또한, 폐미분말의 내부 잔골재 혼입에 의한 강도 부족 및 화학 성분 불균형 문제점을 보완하기 위하여 산업부산물인 고 로슬래그와 비산회를 혼합한 고화체는 처분장 인수기준 을 만족하는 것을 확인하였다. 이렇게 원전 해체과정에 서 발생하는 콘크리트를 이용하여 중·고준위 방사성 폐 기물을 담지한 고화체로 재활용한다면, 혹시 폐콘크리트 에 잔류할 수 있는 방사화된 핵종원소의 고정화로 안전 성 확보가 가능할 것으로 생각된다. 그러나, 원전 해체 폐기물인 중·저준위의 폐토양을 재활용하는 직접적인 연 구는 수행되지 않았다. 하지만, 폐콘크리트를 재생 시멘 트로 재활용할 수 있는 것처럼, 방대한 양의 폐토양도 비 소성 시멘트로 재활용하는 것이 필요할 것으로 판단된다. 폐토양 내 일라이트와 제올라이트와 같은 점토 광물은 방사성 핵종에 대한 흡착능이 우수하다. 폐토양 내 점토 광물을 이용한 비소성 시멘트 제조 시, 다른 흡착제 혼 합 불필요, 원전 해체 폐기물 감소, 방사성 폐기물을 안 전하게 담지할 수 있는 효과를 도출할 수 있다. 이러한 이유에서 폐 토양 내 점토 광물을 재활용한 비소성 시멘 트의 제조에 대한 직접적인 연구의 수행이 필요한 것으 로 사료된다.

\section{Acknowledgement}

본 연구는 국가연구개발 과제(한국에너지기술평가원) 에너지기술개발사업의 지원을 받아 수행되었습니다(과제 번호: 20201520300070).

\section{References}

Abdel Geleel, M. and Mahmoud, N.S. (2012) Improvement of radioactive waste solidification process using modified bentonite materials. Nature and Science, v.10, p.158-164.

Ahn, J.C., Lee, J.H. and Kang, B.H. (2003) Properties of recycle cement made of cementitious powder from concrete waste by conditions of burning. J. Arch. Inst. Kor., Nov;19, p.109-112.

Ahn, J.C. and Park, D.C. (2013) The properties of raw temperature recycled cement using cementitious powder from concrete waste and industrial by-products. J. Arch. Inst. Kor., v.29, p.97-104. 
Binkhorst, I.P. and Cornelissen, H.A.W. (1998) Technology for reuse of contaminated concrete constituents Vienna(Austria): International Atomic Energy Agency(Austria) Report No.: IAEA-TECDOC-1022, p.187.

Byun, K.J., Song, H.W., Kim, H.J. and Lee, H.J. (2004) Property and application of recycled aggregate and recycled aggregate concrete. J. Korea Concr. Inst., v.5, p.135-152.

Cau Dit Coumes, C., Courtois, S., Peysson, S., Ambroise, J. and Péra, J. (2009) Calcium sulfoaluminate cement blended with OPC: a potential binder to encapsulate lowlevel radioactive slurries of complex chemistry. Cem. Concr. Res., v.39, p.740747. doi: 10.1016/j.cemconres.2009.05.016

Cheon, K.H., Choi, J.H., Shin, W.S. and Choi, S.J. (2014) Adsorption characteristics of cobalt, strontium, and cesium on natural soil and kaolin. J. Environ. Sci. Int., v.23, p.1609-1618. doi: 10.5322/jesi.2014.23.9.1609

Cheon, J.H., Lee, S.C., Kim, C.L. and Park, H.G. (2018) Feasibility study on recycling of concrete waste from NPP decommissioning through literature review. J. Rec. Const. Resources, v.6, p.115122. doi: 10.14190/JRCR.2018.6.2.115

Choi, Y.H., Ko, J.H., Lee, D.G., Kim, H.W., Park, K.S. and Sohn, H.D. (2020) Safety assessment for the self-disposal plan of clearance radioactive waste after nuclear power plant decommissioning. J. Energ. Eng., v.29, p.63-74. doi: 10.5855/ ENERGY.2020.29.1.063

Cinquepalmi, M.A., Mangialardi, T., Panei, L., Paolini, A.E. and Piga, L. (2008) Reuse of cement-solidified municipal incinerator fly ash in cement mortars: Physico-mechanical and leaching characteristics. J. Haz. Mat., v.151, p.585-593. doi: 10.1016/ j.jhazmat.2007.06.026

Collins, F.G. and Sanjayan, J.G. (2000) Effect of pore size distribution on drying shrinking of alkali-activated slag concrete. Cem. Concr. Res., v.30, p.1401-1406. http://dx.doi.org/10.1016/ S0008-8846(00)00327-6

El-Kamash, A.M., El-Naggar, M.R. and El-Dessoky, M.I. (2006) Immobilization of cesium and strontium radionuclides in zeolitecement blends. J. Haz. Mat., v.B136, p.310-316. doi: 10.1016/ j.jhazmat.2005.12.020

Hwang, B.I., Kang, S.P. and Kim, S.J. (2018) A study on the factors affecting the strength of alkali-activated slag binders. J. Rec. Const. Resources, v.6, p.130-137. doi: 10.14190/JRCR.2018. 6.2.130

Hwang, J.H., Choung, S.W., Shin, W.S. and Han, W.S. (2018) Study on the illite modification for removal of radioactive cesium in water environment near nuclear facilities. J. Econ. Environ. Geol., v.51, p.113-120. doi: 10.9719/EEG.2018.51.2.113

Im, N.G., Kim, B.U. and Heo, J.W. (2016) Non-fired excellent purification water permeable concrete manufacturing method including illite and functional admixture, KOR Patent 101636978 (registered on 2016.07.07.).

International Atomic Energy Agency (IAEA) (2021)“The database on nuclear power reactors", Power Reactor Information System. Accessed Feb. 20 2021. Available from: http://www.iaea.org/ pris.
Jang, B.J., Kim, S.W., Song, J.H., Park, H.M., Ju, M.K. and Park, C.W. (2013) Fundamental characteristics of carbon-capturing and sequestering activated blast-furnace slag mortar. Int. J. Highw. Eng., v.15, p.95-103. doi: 10.7855/IJHE.2013.15.2.095

Jang, J.Y., Jin, J.H., Cho, G.T., Nam, Y.K. and Jeon, C.K. (2003) Strength characteristics of recycled concrete by recycled aggregate in incheon area waste concrete. J. Korea Concr. Inst., v.15, p.197-208. doi: 10.4334/JKCI.2003.15.2.197

Jeong, J.G., Kim, Y.J., Lee, H.M., Yoo, W.S. and Choi, Y.H. (2017) Evaluation of fundmental properties for the application of generated fine powder during concrete demolition. J. Korea Concr. Inst., Symposium, v.29, p.581-582.

Jo, B.W., Park, M.S. and Park, S.K. (2006) Strength development and hardening mechanism of alkali activated fly ash mortar. J. Korea Concr. Inst., v.18, p.449-458. http://dx.doi.org/10.4334/ JKCI.2006.18.4.449

Jung, S.J., Bang, W.K. and Kim, C.E. (1998) The effects of $\mathrm{Na}_{2} \mathrm{SO}_{4}$ on the hydration of fly ash blended cement. J. Korean Ceram. Soc., v.35, p.1227-1232.

Kang, D.W., Ahn, J.C., Park, D.C., Kim, H.Y. and Kang, B.H. (2011) The basic properties of recycled cement using cementitious powder from waste concrete and industrial by-products. J. Arch. Inst. Kor., Symposium, p.245-248.

Kang, H.Y., Park, S.S. and Han, S.H. (2008) Acid corrosion resistance and durability of alkali-activated fly ash cementconcrete. J. Korean Soc. Environ. Eng., v.30, p.61-68.

Kim, G.W., Kim, B.J., Yang, K.H. and Song, J.K. (2012) Strength development of blended sodium alkali-activated ground granulated blast-furnace slag (GGBS) mortar. J. Korea Concr. Inst., v.24, p.137-145. doi: 10.4334/jkci.2012.24.2.137

Kim, J.H. and Chung, C.W. (2019) Leaching Test for utilizing hydrated cement paste as a solidifying agent for radioactive waste disposal. J. Korea Concr. Inst., Symposium, v.31, p.597598.

Kim, J.H., Seo, E.A. and Chung, C.W. (2020) Performance of waste concrete powder for its potential utilization as a solidifying agent on radioactive waste immobilization. J. Korea Concr. Inst., v.32, p.327-328.

Kim, J.M., Jeong, J.Y., Choi, J.H. and Shin, S.C. (2013) Relationship between compressive Strength and dynamic modulus of elasticity in the cement based solid product for consolidating disposal of medium-low level radioactive waste. J. Korea Concr. Inst., v.25, p.321-329. doi: 10.4334/jkci.2013.25.3.321

Kim, J.M. and Jo, H.Y. (1999) Causes and countermeasures for efflorescence of concrete. KRMCIA, v.1, p.16-25

Kim, J.Y., Park, C.W., Ahn, J.C. and Kang, B.H. (2005) Carbonation properties of recycled cement mortar made of cementitious powder from concrete waste. J. Korea Inst. Build Constr., Symposium, v.5, p.61-64. doi: 10.5345/jkic.2006.6.4.061

Kim, S.B., Kim, Y.S., Kang, S.W., Oh, D.M. and Lee, W.T. (2016) Removal of $\mathrm{Cs}$ and $\mathrm{Sr}$ in water using chemical and natural coagulants. J. Korean Soc. Environ. Eng., v.38, p.662-666. doi: 10.4491/ksee.2016.38.12.662

Kim, Y.K., Jung, U.I. and Kim, B.J. (2015) Compressive strength 
properties of concrete using waste concrete powder as a cement substitute. J. Korea Inst. Build Constr., Symposium, v.15, p.128129.

Koh, K.T., Ryu, G.S. and Lee, J.H. (2010) Properties of the flowability and strength of cementless alkali-activated mortar using the mixed fly ash and ground granulated blast-furnace slag. J. Rec. Const. Resources, v.12, p.114-121.

Koo, D.S., Sung, H.H., Hong, S.B. and Seo, B.K. (2018) Characteristics of solidified cement of electrokinetically decontaminated soil and concrete waste. J. Nucl. Fuel Cycle Waste Technol., v.16, p.83-91. doi: 10.7733/jnfcwt.2018.16.1.83

Lee, B.S. (2020) Trends and prospect in development of domestic and international nuclear power plant decommissioning technology. World Nuclear Power Market Insight, v.8, p.1-40.

Lee, H.J., Seo, E.A., Yang, N.W. and Kim, D.G. (2016) Introduction of decommissioning and dismantling technology for nuclear power plant structure based on domestic and international practices. J. Korea Concr. Inst., v.28, p.8-14.

Lee, K.Y., Oh, M.K., Kim, J.M., Lee, E.H., Kim, I.S., Kim, K.W., Chung, D.Y. and Seo, B.K. (2018) Trends in technology development for the treatment of radioactive concrete waste. J. Kor. Rad. Waste Soc., v.16, p.93-105. doi: 10.7733/jnfcwt.2018. 16.1 .93

Lee, S.H. (2011) Considration of points to be noted for the use of mixed and admixtures in cement and concrete. Cement, v.2011191, p.35-42.

Lee, S.H., Lim, Y.J. and Cho, J.W. (2015) Hydration properties of ordinary portland cement using mixture of limestone and blast furnace slag as minor inorganic additives. J. Korea Concr. Inst., v.27, p.3-9. doi: 10.4334/JKCI.2015.27.1.003

Lee, S.H., Woo, Y.Y. and Cho, D.Y. (2015) Applications and technical status of solidification. J. Rec. Const. Resources, v.10, p.26-32. doi: 10.14190/MRCR.2015.10.2.026

Lee, Y.J., Hwang, D.S., Lee, K.W., Jeong, G.H. and Moon, J.K. (2013) Characterization of cement waste form for final disposal of decommissioned concrete waste. J. Kor. Rad. Waste Soc., v.11, p.271-280. doi: 10.7733/jnfcwt-k.2013.11.4.271

Lim, M.K., Park, M.Y. and Jung, S.J. (2007) A Study of the Strength and durability properties on recycled fine aggregate mortar and blain of blast furance slag. J. Arch. Inst. Kor., v.23, p.91-98.

Malviya, R. and Chaudhary, R. (2006) Factors affecting hazardous waste solidification/stabilization: A review. J. Haz. Mat., v.137, p.267-276. doi: 10.1016/j.jhazmat.2006.01.065

Min, B.Y., Choi, W.K., Lee, K.W. and Park, J.W. (2009) Evaluation of the compressive strength and leachability for cemented waste using radioactive fine powder. J. Nucl. Fuel Cycle Waste Technol., v.26, p.658-666.

Min, B.Y., Park, J.W., Choi, W.K. and Lee, K.W. (2009) Separation of radionuclide from dismantled concrete waste. J. Kor. Rad. Waste Soc., v.7, p.79-86.

Moon, J.G. (2013) Status and prospect of nuclear facility decommissioning technology development. Nuclear Industry, v.33, p.56-59.

Mun, Y.B., Choi, H.K., Kim, J.Y., Lee, J.H., Chung, C.W. and Kim,
J.H. (2017) Recycling waste paste from concrete for solidifying agent, J. Korea Inst. Build Constr. v.17, p.269-277. doi: 10.5345/ JKIBC.2017.17.3.269

Nam, J.H. (2010) Cement concrete pavement for recycling industrial by-products. Int. J. Highw. Eng., v.12, p.20-24.

Oh, S.G. (2005) The physical properties of high-flowability mortar using recyclable cement as cement binder. J. Arch. Inst. Kor., v.21, p.105-112.

Oh, S.G. and Hong, Y.T. (2007) The development of high quality recyclable cement made from waste concrete using micro separating system. J. Arch. Inst. Kor., v.23, p.167-174.

Oh, S.G. and Kim, J.K. (2002) Properties and performance improvement of the recycle cement used waste concrete powder. J. Arch. Inst. Kor., v.18, p.83-90.

Palomo, A., Grutzeck, M.W. and Blanco, M.T. (1999) Alkaliactivated fly ashes, a cement for the future. Cem. Concr. Res., v.29, p.1323-1329. doi: 10.1016/S0008-8846(98)00243-9

Park, C.W., Ahn, J.C. and Kang, B.H. (2004) A study on the technique to manufacture recycled cement from cementitous powders for complete recycling of concrete structures. J. Korea Inst. Build Constr., v.4, p.143-151. doi: 10.5345/JKIC.2004.4.3.143

Park, C.W. and Kang, B.H. (2004) A study on hydration properties of recycled cement mortar using admixture materials. J. Korea Inst. Build Constr., v.4, p.79-86. doi: 10.5345/JKIC.2004.4.4.079

Park, H.S., Kim, I.T., Kim, H.Y., Ruy, S.K. and Kim, J.H. (2004) General approach to stabilization/solidification of radioactive wastes. J. Korea Nuclear Society, Symposium(2004-spring), p.114.

Park, S.S., Kang, H.Y. and Han, K.S. (2007) Development of fly ash/slag cement using alkali-activated reaction(1) compressive strength and acid corrosion resistance. J. Korean Soc. Environ. Eng., v.29, p.801-809.

Qin, L. and Gao, X.J. (2019) Recycling of waste autoclaved aerated concrete powder in portland cement by accelerated carbonation. Waste Manage., v.89, p.254-264. doi: 10.1016/j.wasman.2019.04.018

Qin, L. and Gao, X.J. (2019) Properties of coal gangue-portland cement mixture with carbonation. Fuel, v.245, p.1-12. doi: 10.1016/j.fuel.2019.02.067

Saleh, H.M., El-Sheikh, S.M., Elshereafy, E.E. and Essa, A.K. (2019) Performance of cement-slag-titanate nanofibers composite immobilized radioactive waste solution through frost and flooding events. J. Con. Build Mat., v.223, p.221-232. doi: 10.1016/ j.conbuildmat.2019.06.219

Sasaki, T., Sone, T., Koyama, H. and Yamaguchi, H. (2009) Steamassisted pyrolysis system for decontamination and volume reduction of radioactive organic waste. J. Nucl. Sci. Techol., v.46, p.232-238. doi: 10.1080/18811248.2007.9711526

Sawada, K., Uruga, K., Koyama, T., Shimada, T., Mori, Y. and Enokida, Y. (2005) Stoichiometric relation for extraction of uranium from $\mathrm{UO} 2$ powder using TBP complex with $\mathrm{HNO}_{3}$ and $\mathrm{H}_{2} \mathrm{O}$ in supercritical $\mathrm{CO}_{2}$. J. Nucl. Sci. Techol., v.42, p.301-304. doi: 10.1080/18811248.2005.9726394

Shi, C. and Fernández-Jiménz, A. (2006) Stabilization/solidification of hazardous and radioactive wastes with alkali-activated 
cements. J. Haz. Mat., v.137, p.1656-1663. doi: 10.1016/ j.jhazmat.2006.05.008

Shin, S. W. (2003) Development of high performance concrete using recycled aggregate. J. Korea Concr. Inst., v.15, p.52-59.

Shin, T.S., Hong, S.P. and Kim, K.Y. (2013) Assessment of leaching characteristics of alkaline and heavymetal ions from recycled concrete aggregate. J. Environ. Impact Asees., v.22, p.427-437. doi: 10.14249/eia.2013.22.5.427

Song, J.S. (2016) Current status and future of nuclear power plant decommissioning waste treatment technology. KEITI, v.134, p.113.

Tian, Q. and Sasaki, K. (2019) Application of fly ash-based materials for stabilization/solidification of cesium and strontium.
Environ. Sci. Pollut. Res., v.26, p.23542-23554. doi: 10.1007/ s11356-019-05612-1

Yang, K.H. and Song, J.G. (2007) The properties and applications of alkali-activated concrete with no cement. J. Korea Concr. Inst., v.19, p.42-48. doi: 10.22636/MKCI.2007.19.2.42

Ye, S., Feng, P. and Zhang, W. (2020) Rapid solidification of portland cement/polyacrylamide hydrogel (PC/PAM) composites for diverse wastewater treatments. RSC Adv., v.10, p.1893618944. doi: 10.1039/d0ra03025b

Yeon, I.J., Ju, S.Y., Lee, S.W., Shin, T.S. and Kim, K.Y. (2008) The solidification characteristics of recycled aggregate mixed with incineration ash and waste concrete. J. Kor. Geo-Environ. Soc., v.9, p.5-13. 